\title{
Faculty-librarian collaborative culture in the universities of Hong Kong, Singapore, Taiwan, and Thailand: A comparative study
}

\author{
$\mathrm{Ti} \mathrm{Yu}^{1 *}$, Chao-chen Chen ${ }^{2}$, Christopher Khoo ${ }^{3}$, Sujin Butdisuwan ${ }^{4}$, Leo Ma ${ }^{5}$, \\ Chutima Sacchanand ${ }^{6}$ and Kulthida Tuamsuk ${ }^{7}$ \\ ${ }^{1}$ College of Humanities and Design, Jinwen University of Science and Technology \\ No. 99, Anzhong Rd., Xindian Dist., New Taipei City, TAIWAN \\ ${ }^{2}$ Graduate Institute of Library and Information Studies, National Taiwan Normal University \\ ${ }^{3}$ Nanyang Technological University, SINGAPORE \\ ${ }^{4}$ Faculty of Informatics, Mahasarakham University, THAILAND \\ ${ }^{5}$ New Asia College Ch'ien Mu Library \& United College Wu Chung Multimedia Library, \\ Chinese University of Hong Kong, HONG KONG \\ ${ }^{6}$ Sukhothai Thammathirat Open University, THAILAND \\ ${ }^{7}$ Faculty of Humanities and Social Sciences, Khon Kaen University, THAILAND \\ e-mail: tiyu@just.edu.tw* (corresponding author); cc4073@ntnu.edu.tw; \\ ASSGKHOO@ntu.edu.sg; sujin.b@msu.ac.th; leoma@lib.cuhk.edu.hk; \\ chutimastou@gmail.com; kultua@kku.ac.th
}

\begin{abstract}
This study considers that "collaborative culture" is the basis for faculty members and librarians to work together in higher education institutions. The study therefore attempts to explore the collaboration between faculty members and librarians from the perspective of culture. It can not only provide an opportunity to elucidate the current development of the faculty-librarian collaboration in some parts of Southeast Asia such as Hong Kong, Singapore, Thailand, and Taiwan, but also compare the distinctions in the value of faculty-librarian collaborative culture. It also aims to describe and evaluate the perceptions/experiences toward the current development of faculty-librarian collaboration in universities in these different countries. Two online questionnaires, entitled "Faculty-librarian Collaboration Survey-Librarian" and "Faculty-librarian Collaboration Survey-Faculty", were designed and developed by the researchers to collect data. 480 valid responses were collected from December 2015 to May 2016. Seven key elements were investigated in this study that can represent the content and concept of faculty-librarian collaborative culture. They are: (1) Organizational collaborative
\end{abstract}


environment; (2) Mutual benefit and responsibility in collaboration; (3) Collaborative commitment; (4) Collaborative leadership; (5) Mutual understanding and communication; (6) Mutual respect and trust; and (7) Collaborative relationship and interaction. It was concluded that the responding faculty members and librarians in different regions of Southeast Asia, including Hong Kong, Singapore, Thailand, and Taiwan exhibited distinctions in the value levels of faculty-librarian collaborative culture, as well as in the perceptions/experiences toward the current development of faculty-librarian collaboration. Finally, a number of implications and suggestions were proposed by the researchers for librarians and faculty members to develop faculty-librarian collaborations in Hong Kong, Singapore, Thailand, and Taiwan, respectively.

Keywords: Faculty-librarian collaboration; Collaborative culture; Academic libraries; Hong Kong; Singapore; Taiwan; Thailand

\section{INTRODUCTION}

Over the past few decades, due to various challenges and changes, such as the rapid development of information technology, manpower constraints, rigid evaluation, and increased competition in higher education, numerous faculty and administrative staff members have come to recognize the pressures involved in the improvement of student's learning, faculty's teaching and research, and institutional performances. As a result, collaboration has become one of the most beneficial approaches for faculty members and librarians to cope with these challenges and changes (Casper and Lenn 2000; Raspa and Ward 2000; Wijayasumdara 2008).

Librarians have been working together with faculty members for a long time to implement library instruction, conduct cooperative teaching classes, design library assignments, compose research project proposals, develop library collections, and so forth (Jeffries 2000). A survey by Library Journal and Gale (2015) identified four key services for academic librarians and faculty members when collaborating with each other in US: "instruction of students in information literacy,"; "development of collections in direct support of course curricula,"; "aiding students one-on-one in conducting research," and "development of discipline-wide collections".

Several experts and scholars, however, have expressed rather negative viewpoints regarding collaborations between faculty members and librarians. For example, Hardesty $(1991 ; 1995)$ argues that librarians hardly ever appreciated the values of faculty members and tend not to understand the complexities of faculty culture. As a result, it was often not easy for librarians 


\section{Yu, T. et al.}

to work effectively with faculty members. Concerning issues of professional status, Segal (1999) points out that "status of identity" was a critical factor in influencing the collaboration between faculty members and librarians. The study specifically addresses the struggle of librarians to gain academic recognition. Jenkins (2005) reports that librarians frequently find it difficult to gain respect from faculty members because most of them do not possess Ph.D. degrees, subject specialization, or research skills. Consequently, it could be difficult for librarians to successfully collaborate with faculty members as a crucial gap may exist between them. This gap may also be caused by their different cultural attitudes and unfamiliarity with each other.

During the past twenty years, experts and scholars in librarianship worldwide have advocated the importance of forming collaborative relationships and initiating collaborative projects between librarians and faculty members (Hardesty 1995; Farber 1999; Rockman 2001; Doskatsch 2003; Jenkins 2005; Kraat 2005; Wijayasundara 2008; Cha and Hsieh 2009; Yu and Huang 2009). The researchers agree with these scholars' assertions, but do not believe that forming a good collaborative relationship or initiating a collaborative project can successfully sustain the faculty-librarian collaboration over a long period of time. The researchers consider that factors related to notions of "culture" is probably the critical issue determining the success of a long-term collaboration between faculty members and librarians.

"Culture" is a complex concept and has been defined in numerous ways. When we apply it to groups and organizations, culture can be a kind of socialization process that influences and reflects the values, beliefs, attitudes, and behaviors of the members in a group or an organization (Schein 1992). No matter how culture is defined, however, it is often linked with the success of educational organizations, and can play a significant role in modeling organizational members' behaviors (Mees 2008). Two main issues can be identified: first, the role of culture in determining effective collaboration; and second, how is it related to the success of collaboration in a group or an organization. Collaborative culture tends to involve shared values, beliefs, and behaviors. All these elements can facilitate group members working together towards a common goal, process, or product (Southern 2005). Given the importance of these variables, the influence of a collaborative culture in group organizations is paramount. Therefore, the culture of collaboration can probably be considered as the basis for faculty members and librarians to collaborate with each other. It may also be considered the key component for successful long-term collaboration between them and other staff members in a university setting. 
Since collaborative culture is related to the culture of an organization, the researchers consider that it can also influence the members of a society and can be influenced by national culture. Through referring to previous studies, the researchers found that most studies on the topic of collaboration between faculty members and librarians were conducted in the Western cultures, such as North America and Australia. However, few studies have been conducted by librarians and scholars in Asia. Furthermore, the researchers also found that very few studies focused on the collaborative culture between faculty members and librarians in either the East or the West.

Accordingly, the researchers aim to explore the collaboration between faculty members and librarians from the perspective of culture and determine the elements that can enhance faculty-librarian collaboration. In addition, the researchers also attempt to extend the geographical range of the investigation to cover several countries and regions in Southeast Asia, including Hong Kong, Singapore, Taiwan, and Thailand. This can not only provide an opportunity to elucidate the current development of the faculty-librarian collaboration in some parts of Asia, but also compare the distinctions in the value of collaborative culture between faculty members and librarians in universities in these countries.

\section{LITERATURE REVIEW}

This study reviews scholarly literature to connect the concepts and issues that have been proposed above. The literature review focuses on four areas. First, the definitions and elements of faculty-librarian collaboration are discussed. Second, a number of studies regarding the current development of faculty-librarian collaboration in countries in Asia are reviewed. Third, the concepts of faculty-librarian collaborative culture are investigated. Finally, the relationship between national culture and collaborative culture is examined.

\section{Faculty-Librarian Collaboration}

The term "collaboration" is frequently used synonymously with certain words, such as cooperation, coordination, coalition, network, alliance, partnership, and bridge (Huxham 1996). Wagner (1998) defined, "collaboration is a process of action in which everyone works to understand the problem, engage in discussion to reach agreement on the goal, and shares responsibility for implementing change, assessing progress, and achieving results (p. 517)."

With respect to the faculty-librarian collaboration, several crucial elements are involved according to the definitions and concepts of Mattessich and Monsey (1992), Raspa and Ward (2000), and Cook (2000). They are: (1) collaborative relationship: this is the first step, in which both librarians and faculty members are willing to establish a formal or informal collaborative 


\section{Yu, T. et al.}

relationship; (2) common goal: understanding the reasons and objectives involved in a collaborative project is needed; (3) shared responsibility: clarifying the duties and tasks between librarians and faculty required for a collaborative project; (4) mutual benefit: both librarians and faculty can obtain benefits in a collaborative project; (5) collaborative process: collaboration must be a well-structured process of action for achieving a common goal; and (6) organizational performance: improving organizational effectiveness is the final goal (e.g., improvement of teaching and learning).

There are a number of studies regarding faculty-librarian collaboration at colleges and universities in the Asian region. Cha and Hsieh (2009) conducted a survey at Feng Chia University in Taiwan in order to understand faculty's attitudes toward collaboration with librarians to integrate information literacy into their curriculum. They found that nearly half of the faculty members were willing to collaborate with librarians to design information literacy hands-on activities for different learning units. They also concluded that librarians, with knowledge of pedagogy and progress in library professionalism, can contribute to consolidating faculty-librarian partnerships when developing course-specific information literacy programs. Yu and Huang (2009) proposed five key success factors for faculty-librarian collaboration according to the results of the faculty's survey at Jinwen University of Science and Technology in Taiwan. They are: (1) to build active relationships with the teaching faculty; (2) to obtain support and commitment from the school authority; (3) to state clearly the rights and obligations for the teaching faculty as a formal school policy; (4) to establish a reward policy for encouraging teaching faculty to collaborate with the library staff; and (5) to understand the needs of the teaching faculty and continue communicating with them.

Maitaouthong, Tuamsuk and Tachamanee (2011) surveyed administrators, lecturers, and librarians at Srinakharinwirot University in Thailand. Their aim was to define the factors affecting the integration of information literacy in the teaching and learning processes of general education courses. They found that "Cooperation between lecturers and librarians" was one of 11 factors and ranked number five. They also summarized eight types of cooperative models between lecturers and librarians in that study. In addition, they conducted another study in 2012. They surveyed 42 librarians about their experiences in teaching/co-teaching undergraduate courses. "Preparing exercises/assignments", "establishing teaching activities", "preparing information resources that support students' learning", "preparing computer laboratory and teaching materials and equipment", and "assessing and evaluating students' learning outcome" are the five most frequent activities adopted by librarians when they are co-teaching with lecturers (Maitaouthong, Tuamsuk and Tachamanee 2012). 
Andayani (2017) described an initiative program of institutional repository development at the Syarif Hidayatullah State Islamic University in Jakarta, Indonesia. In this program, librarians cooperated and collaborated with faculty members in the implementation processes of institutional repositories, including content recruitment, content preparation, and submission. In that study, the author concluded that the professional partnership between librarians and faculty members is the foundation of the successful development of institutional repositories in the university.

There have also been a number of studies focusing on collaborations between teachers and librarians in primary and/or secondary schools in the Asian region. Lo et al. (2014) surveyed the roles and expectations of school librarians as information literacy instructors between Hong Kong, Japan, Shanghai, South Korea, and Taipei. Chu, Chow, and Tse (2011) implemented a project that involved combining a collaborative teaching approach with inquiry project-based learning (PBL), and brought together a team of teachers with different specialties and the school librarian to develop students' IT skills and information literacy in a Hong Kong primary school. Mokhtar and Majid (2005; 2006) investigated the level of collaboration between teachers and librarians in primary and secondary schools based on a survey of 76 teachers from seven schools in Singapore. They discovered that teachers typically did not collaborate with their school librarians in planning their lessons or other academic activities, and teachers had yet to regard the school librarians as educational partners.

In summary, the importance of collaboration between teachers/faculties and librarians was recognized in most areas of the Asian region, especially regarding the relation of information literacy education. Evidently, the success of the collaboration seemed to be influenced by the support of school administrators and leaders, as well as the level of familiarity existing between teachers/faculties and librarians. On the other hand, the researchers discovered that the topics regarding faculty-librarian collaboration in colleges and universities have been widely discussed and studied, mostly in Thailand and Taiwan.

\section{Faculty-Librarian Collaborative Culture}

The term "collaborative culture" mainly refers to shared values, beliefs, and behaviors that facilitate working together toward a common goal, process, or product (Southern 2005). For this study, faculty-librarian collaborative culture can be defined as a set of shared norms, values, beliefs, attitudes, and behaviors between faculty members and librarians. These may serve to facilitate working together in order to perform collaborative projects. These include a number of joint tasks: implementing an information literacy program, designing a library assignment, developing the library collection, preparing teaching materials, composing a 
research project proposal and organizing workshops.

It is difficult to find a specific theory which can adequately describe and explain the collaborative culture phenomenon. Most ideas in relation to collaborative culture are derived from the concepts and theories of organizational culture. Srivastave and Banaji (2011), for instance, adapted Schein's three-level model of organizational culture to describe the concept of collaborative culture, as shown in Figure. 1. They assumed that collaborative culture can be expressed in the first level of "artifacts". This consists of formalized decision processes that stress consultation in work units. The second level refers to "espoused beliefs", such as broadly disseminated value statements that advocate collaboration The third level concerns "underlying assumptions". These involve taken-for-granted notions which need to be clarified in order assist staff when working with colleagues in other units. These are considered the key components of success in an organization. Once the collaborative culture is established, it can create strong pressures for members in an organization to present themselves to others in a manner that is consistent with collaborative norms.

Based on the above concepts, the researchers aim to adopt Schein's three levels of culture model as the theoretical framework. In this way, it is possible to analyze faculty-librarian interaction and collaborative culture. The model can be further developed as an instrument for measuring the levels of collaborative culture valued by librarians and faculty members in higher education institutions in Hong Kong, Singapore, Taiwan, and Thailand.
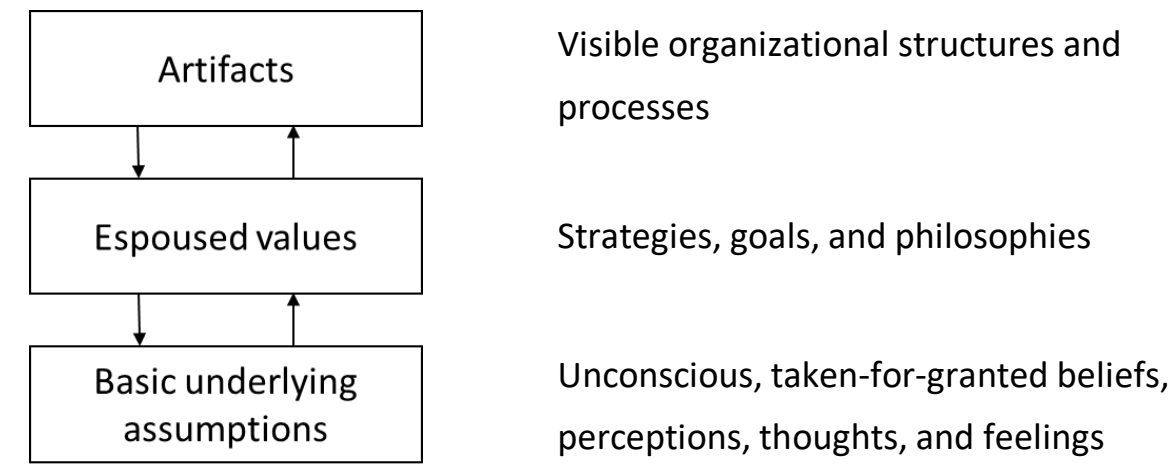

Figure 1. Schein's Three-level Model of Organizational Culture (Schein 1992, p. 17)

\section{Relationship of National Culture and Collaborative Culture}

Cox, Lobel and McLeod (1991) posit that people with different ethnic backgrounds possess different attitudes, values, and norms that reflect their cultural heritage. In other words, those from different countries reflect varied national cultures. Accordingly, whether or not a faculty-librarian collaborative culture can be successfully created in an organization, a society, 
and even a country is likely to be influenced by the national culture.

In fact, several empirical studies have proven that people with different cultural backgrounds may possess distinct values regarding collaborative culture (Cox, Lobel, and McLeod 1991; Wei 2009; Siakas, Georgiadou and Balstrup 2010; Magnusson, Peterson and Westjohn 2014). For example, in the study of Cox, Lobel, and McLeod (1991), it has been confirmed that groups composed of people from collectivist cultural traditions would exhibit more cooperative behavior than groups composed of people from individualistic cultural traditions. This implies that faculty members and librarians from collectivist cultural traditions may demonstrate a higher level of value in collaborative culture than those who have individualistic cultural traditions. In this study therefore, the researchers also attempt to examine the distinctions in collaborative culture between faculty and librarians in different countries and areas of Southeast Asia, including Hong Kong, Singapore, Taiwan, and Thailand. There is an additional investigation into the current development of faculty-librarian collaboration in these areas.

\section{RESEARCH QUESTIONS}

Based on the concepts noted above and the review of the current literature, this study proposes the following three main research questions and five subsidiary research questions:

a) What are the key elements for constructing a positive faculty-librarian collaborative culture?

b) What are the distinctive attributes regarding the values of faculty-librarian collaborative culture in universities in Hong Kong, Singapore, Taiwan, and Thailand?

c) What are the intrinsic differences in the perceptions/experiences of the current development regarding faculty-librarian collaboration in universities in Hong Kong, Singapore, Taiwan, and Thailand?

(i) In what ways do the reasons for developing faculty-librarian collaboration differ?

(ii) To what extent do the approaches for building faculty-librarian collaborative relationships differ?

(iii) What are the common qualities regarding valid models for developing facultylibrarian collaboration?

(iv) Which set of factors contribute to effective and successful faculty-librarian collaboration?

(v) What are common difficulties faced by faculty members and librarians when engaging in faculty-librarian collaborative projects? 


\section{METHOD}

This study selects Hong Kong, Singapore, Taiwan, and Thailand in Southeast Asia as the targets of investigation. One of the reasons for this choice is because the development of library and information studies in these four Southeast Asian countries is relatively advanced. The other reason is that these four countries are also active members of ALIRG (Asian Library and Information Research Group).

This study adopts Schein's three-level model of organizational culture as the theoretical framework. It is utilized to explore the dimensions and factors to depict the contents for structuring a culture of collaboration between faculty members and librarians in universities. Twenty-four factors were extracted based on the relevant literature and one-on-one interviews with faculty members and senior professional librarians in Taiwan. The researchers grouped these 24 factors into seven dimensions according to their features. The names of the seven dimensions were also temporarily given by the researchers. The seven dimensions and 24 factors are grouped into three levels of culture as shown in Table 1.

\section{Research Instrument}

In this study, a questionnaire survey was conducted in order to collect data. First, two draft versions of the questionnaires for librarian and faculty were designed and developed by the researchers. They are based on a review of the relevant literature and the seven dimensions and 24 factors cited above. One is "Faculty-librarian Collaboration Survey--Librarian" for librarians to reply. The other is "Faculty-librarian Collaboration Survey--Faculty" for faculty members to respond. In fact, most of the question statements are the same for both questionnaires. For example, the statement of Q1 for librarians is "I often keep in touch with faculty members." On the contrary, the statement of Q1 for faculty members becomes "I often keep in touch with librarians." Actually, the meanings of the two statements are identical. Since the survey questionnaires should be distributed to different countries and areas, each survey questionnaire has two language versions, Chinese and English. The first part is demographic and background information. The second part is Faculty-librarian Collaborative Culture (FLCCQ), with 47 question items to measure the levels of values of faculty members and librarians regarding faculty-librarian collaborative culture. The third part is composed of five question items. They are designed to determine the experiences and/or perceptions of faculty members and librarians regarding the current development of faculty-librarian collaboration. Both part two and three were designed as a five-point Likerttype scale. Finally, an open-ended question was designed at the end of the third part to ask the respondents to talk about their personal experience in faculty-librarian collaborative projects. 
Table 1: Grouping Analysis in the Three Levels of Culture, Dimensions, and Factors for Constructing Faculty-Librarian Collaborative Culture

\begin{tabular}{|c|c|c|}
\hline Three levels of culture & Dimensions & Factors \\
\hline \multirow{6}{*}{ Artifacts } & Organizational collaborative & 1. Formalization \\
\hline & structure & 2. Power distance \\
\hline & \multirow{4}{*}{ Collaborative environment } & 3. Physical environment \\
\hline & & 4. Collaborative climate in the \\
\hline & & community \\
\hline & & 5. Institutional commitment \\
\hline Espoused values & Collaborative leadership & 6. Leadership beliefs and behaviors \\
\hline \multirow{20}{*}{$\begin{array}{l}\text { Basic underlying } \\
\text { assumptions }\end{array}$} & \multirow{5}{*}{ Communication } & 7. Interpersonal contact and \\
\hline & & interaction \\
\hline & & 8. Listening \\
\hline & & 9. Formal and informal \\
\hline & & communication \\
\hline & \multirow{3}{*}{ Mutual relationship } & 10. Mutual understanding \\
\hline & & 11. Mutual benefit \\
\hline & & 12. Mutual respect and trust \\
\hline & \multirow{7}{*}{$\begin{array}{l}\text { Fundamental qualities of } \\
\text { collaboration }\end{array}$} & 13. Passion \\
\hline & & 14. Persistence \\
\hline & & 15. Playfulness \\
\hline & & 16. Project \\
\hline & & 17. Promotion \\
\hline & & 18. Common goals \\
\hline & & 19. Shared responsibility \\
\hline & \multirow{5}{*}{ Collaborative performance } & 20. Faculty teaching performance \\
\hline & & 21. Faculty research performance \\
\hline & & 22. Student learning achievement \\
\hline & & 23. Library service performance \\
\hline & & 24. Organizational performance \\
\hline
\end{tabular}

Two senior professional librarians and three scholars in librarianship of Taiwan were then invited to respond to the questionnaires and provide comments for editing the questionnaires in May and June, 2015. The questionnaires were then presented at the $7^{\text {th }}$ ALIRG Workshop at Manila in October, 2015. A number of useful comments were provided by several scholars at this seminar. In addition, 28 librarians and 35 faculty members at several Taiwanese' universities were asked to pretest the questionnaires in September and October, 2015. Finally, two final versions of the survey questionnaires were developed by the 
researchers in November, 2015. The Chinese version of the questionnaire has been used by $\mathrm{Yu}$ and Chen (2018) to conduct a survey study regarding faculty-librarian collaboration in Taiwan.

The questionnaire was perceived to be readable and understandable to all 63 pilot pre-test members, demonstrating that the questionnaire had acceptable content validity. Factor analysis was used to assess the construct validity of the instruments. According to the pretest results, nine question items were removed due to low factor loadings $(<0.5)$ and low critical ratio $(<0.3)$. Consequently, the final version of the FLCCQ consisted of 38 question items. The reliability of the FLCCQ had a Cronbach's alpha of 0.943 . In addition, the reliability of Q1, Q2, Q3, Q4, and Q5 for the third part of the questionnaire had a Cronbach's alpha of $0.870,0.885,0.890,0.938$, and 0.906 , respectively. This indicates a significant high level of internal consistency for the full questionnaire.

\section{Sampling and Data Collection}

In this study, the online survey tool, SurveyMonkey, was used to collect data via the Internet. Since it was impossible to ask all of the faculty members and librarians in the universities of Hong Kong, Singapore, Thailand, and Taiwan to fill out the questionnaire, it was decided to adopt convenience sampling and snowball sampling approaches to collect data. All collaborators of this research project actively asked scholars, professors, librarians, and publishers who they know in Hong Kong, Singapore, Thailand, and Taiwan to reply to the questionnaire. In order to obtain as many replies as possible, they also asked their friends and friends' friends to help distribute the questionnaires. As a result, 612 respondents answered the online questionnaire in total from December 2015 to May 2016. However, 132 responses were highly incomplete. This resulted in 480 valid responses, for an overall valid response rate of 78.43 percent.

\section{RESULTS AND DISCUSSIONS}

\section{Background Characteristics of the Respondents}

In Table 2, most of the respondents for this study are from Taiwan (39.8\%), followed by Thailand (38.8\%), Hong Kong (11.6\%), and Singapore (9.8\%). With respect to the job position, 191(39.8\%) faculty members and 289 (60.2\%) librarians replied to the questionnaire. Regarding experience in faculty-librarian collaboration, it is surprising that over $95 \%$ of the responding faculty members and librarians have collaborated with each other previously. This finding gives librarians a strong belief that faculty-librarian collaboration is feasible in universities of Southeast Asia, including Hong Kong, Singapore, Taiwan, and Thailand. 
Table 2: Distribution of Respondents' Background Characteristics ( $N=480$ )

\begin{tabular}{|c|c|c|c|}
\hline \multicolumn{2}{|c|}{ Demographic information } & \multirow{2}{*}{ No. of responses } & \multirow{2}{*}{$\begin{array}{r}\% \\
39.8\end{array}$} \\
\hline Job position & Faculty members & & \\
\hline & Librarian & 289 & 60.2 \\
\hline \multirow[t]{4}{*}{ Location of university } & Taiwan & 191 & 39.8 \\
\hline & Hong Kong & 56 & 11.7 \\
\hline & Thailand & 186 & 38.8 \\
\hline & Singapore & 47 & 9.8 \\
\hline \multirow[t]{2}{*}{ Category of university } & Public & 324 & 67.5 \\
\hline & Private & 156 & 32.5 \\
\hline \multirow[t]{3}{*}{ Type of university } & Research-oriented & 171 & 35.6 \\
\hline & Teaching-oriented & 189 & 39.4 \\
\hline & Technology-oriented & 120 & 25.0 \\
\hline \multirow[t]{4}{*}{ Student size of university } & 0-9999 & 188 & 39.2 \\
\hline & 10000-19999 & 123 & 25.6 \\
\hline & 20000-29999 & 71 & 14.8 \\
\hline & 30000 or above & 98 & 20.4 \\
\hline \multirow[t]{4}{*}{ Staff size of university library } & $1-19$ & 186 & 38.8 \\
\hline & $20-49$ & 101 & 21.0 \\
\hline & $50-99$ & 85 & 17.7 \\
\hline & 100 or above & 108 & 22.5 \\
\hline \multirow{2}{*}{$\begin{array}{l}\text { Experience in faculty-librarian } \\
\text { collaboration }\end{array}$} & Yes & 458 & 95.4 \\
\hline & Never & 22 & 4.6 \\
\hline
\end{tabular}

\section{Elements of Faculty-Librarian Collaborative Culture}

For this study, seven dimensions of constructing faculty-librarian collaborative culture were extracted according to the results of factor analysis. However, there are some differences between the final version and the previous version of the seven dimensions (see Table 1). The names of the seven dimensions in the final version were also given by the researchers, which are: (1) Organizational collaborative environment; (2) Mutual benefit and responsibility in collaboration; (3) Collaborative commitment; (4) Collaborative leadership; (5) Mutual understanding and communication; (6) Mutual respect and trust; and (7) Collaborative relationship and interaction.

The strongest dimension of faculty-librarian collaborative culture in the universities of Hong Kong, Singapore, Thailand, and Taiwan is "Mutual respect and trust" (average=4.17), followed by "Mutual benefit and responsibility in collaboration" (average=4.14), according to the results in Table 3. This indicates that most faculty members and librarians exhibit a 
high degree of trust and respect for each other, and most of them agree that faculty-librarian collaboration can bring various mutual benefits.

In contrast, both dimensions of "Organizational collaborative environment" (average=3.27) and "Collaborative leadership" (average=3.55) exhibited a weaker response level in facultylibrarian collaborative culture. This indicates that most administrative leaders either in academic departments or libraries of universities in Hong Kong, Singapore, Thailand, and Taiwan have not yet demonstrated strong support for their faculty and staff members to collaborate with each other. This suggests that a collaborative atmosphere between faculty members and librarians has not yet been formally established in most of the respondents' universities.

Table 3: Comparison of the Value Levels of Faculty-Librarian Collaborative Culture in Seven Dimensions

\begin{tabular}{lllcc}
\hline \hline \multicolumn{1}{c}{ Dimension } & \multicolumn{1}{c}{ Items } & Average & SD \\
\hline \hline 1. $\begin{array}{l}\text { Organizational collaborative } \\
\text { environment }\end{array}$ & $31,32,33,34,35,36,37,38$ & 3.27 & 0.86 \\
2. Mutual benefit and responsibility & $21,22,23,24,25,26$ & 4.14 & 0.65 \\
3. Collaborative commitment & $15,16,17,18,19,20$ & 3.76 & 0.73 \\
4. Collaborative leadership & $27,28,29,30$ & 3.55 & 0.86 \\
5. Mutual understanding and & $1,5,6,7,8,9,14$ & 3.80 & 0.81 \\
& communication & $3,10,11,12$ & & \\
6. Mutual respect and trust & $2,4,13$ & 4.17 & 0.63 \\
7. Collaborative relationship and & & 3.91 & 0.74 \\
& interaction & & \\
\hline \hline
\end{tabular}

\section{Distinctions in the Values of Faculty-Librarian Collaborative Culture}

Based on the statistical results of mean scores for each location of university as shown in Table 4, the responding faculty members and librarians working for the universities in Thailand exhibit the highest level of value concerning the dimensions of "Organizational collaborative environment" and "Mutual understanding and communication." This result infers that a collaborative atmosphere has been formally or informally created between faculty members and librarians in the universities of Thailand. It appears to be more than in the universities Hong Kong, Singapore, and Taiwan, faculty members and librarians in Thailand tend to have better relationships in terms of communication than those in Hong Kong, Singapore, and Taiwan. These results suggest that there is a cause and effect relationship between organizational environment and mutual communication for faculty members and librarians. It may well motivate staff to successfully collaborate with each other 
in the universities.

Table 4: Comparison of the Values in Seven Dimensions of Faculty-Librarian Collaborative Culture in Hong Kong, Singapore, Taiwan, and Thailand

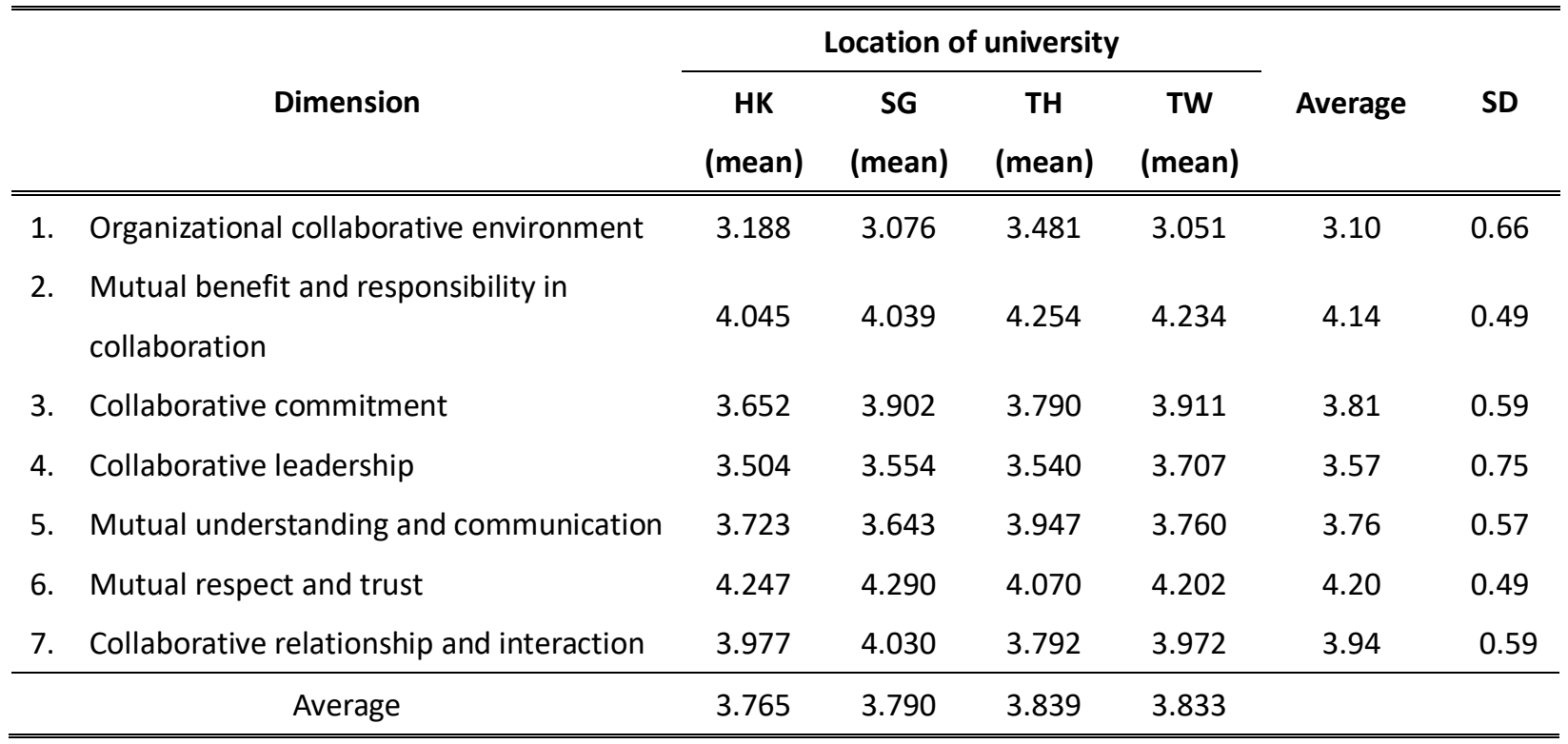

Note: $1 . \mathrm{N}=480 ; 2$.HK=Hong Kong, $\mathrm{SG}=$ Singapore, $\mathrm{TH}=$ Thailand, $\mathrm{TW}=$ Taiwan

With respect to the dimension of "Collaborative commitment", the responding faculty members and librarians both in Taiwan and Singapore show a higher level of value than those respondents in Hong Kong and Thailand. This indicates that the responding faculty members and librarians in Taiwan and Singapore prefer to spend more time and effort working together. The level of participation in faculty-librarian collaborative project appears higher compared with those in Hong Kong and Thailand. In addition, in the dimension of "Collaborative leadership", the respondents in Taiwan exhibit the highest level of value. This result implies that the responding faculty members and librarians in Taiwan gain more support from leaders than those who are in Hong Kong, Singapore, and Thailand.

In the dimensions of "Mutual respect and trust" and "Mutual benefit and responsibility in collaboration", all of the mean scores of each region were above 4.0. It may be inferred that most of the responding faculty members and librarians in Hong Kong, Singapore, Thailand, and Taiwan respect and trust each other. They may therefore be more willing to implement the collaborative projects together in order to improve their teaching and working performance.

Furthermore, faculty members and librarians in Thailand (average $=3.839$ ) possess the highest level of value in faculty-librarian collaborative culture, followed by Taiwan (average $=3.833$ ), Singapore (average $=3.790$ ) and Hong Kong (average $=3.762$ ). In general, this 
result indicates that faculty members and librarians both in Thailand and Taiwan tend to have a slightly higher level of value than those who are in Hong Kong and Singapore regarding faculty-librarian collaborative culture. In the current literature, the relevant research topics regarding faculty-librarian collaborations have been discussed and studied in Thailand and Taiwan to a greater extent than in Hong Kong and Singapore.

\section{Distinctions in the Perceptions/Experiences of the Current Development of Faculty- Librarian Collaboration}

\section{(a) Reasons for developing faculty-librarian collaboration}

As shown in Table 5, it is clear that the most significant reason for the responding faculty members and librarians to collaborate with each other is "To promote information literacy education" (average=4.49), followed by "To promote the use of library resources and services" (average $=4.42$ ). This implies that the majority of the responding faculty members and librarians in universities of Hong Kong, Singapore, Thailand, and Taiwan regard information literacy education and library instruction as highly important.

Table 5: Comparison of the Differences in the Reasons for Developing Faculty-Librarian Collaboration in Hong Kong, Singapore, Taiwan, and Thailand

\begin{tabular}{|c|c|c|c|c|c|c|}
\hline \multirow[b]{2}{*}{ Reason } & \multicolumn{4}{|c|}{ Location of university } & \multirow[b]{2}{*}{ Average } & \multirow[b]{2}{*}{ SD } \\
\hline & $\begin{array}{c}\text { HK } \\
\text { (mean) }\end{array}$ & $\begin{array}{c}\text { SG } \\
\text { (mean) }\end{array}$ & $\begin{array}{c}\text { TH } \\
\text { (mean) }\end{array}$ & $\begin{array}{c}\text { TW } \\
\text { (mean) }\end{array}$ & & \\
\hline $\begin{array}{l}\text { 1. To promote the use of library resources and } \\
\text { services }\end{array}$ & 4.16 & 4.32 & 4.42 & 4.51 & 4.42 & 0.62 \\
\hline 2. To promote information literacy education & 4.41 & 4.47 & 4.62 & 4.40 & 4.49 & 0.60 \\
\hline $\begin{array}{l}\text { 3. To improve the teaching performance of } \\
\text { faculty members }\end{array}$ & 3.79 & 3.87 & 4.32 & 4.14 & 4.14 & 0.73 \\
\hline $\begin{array}{l}\text { 4. To improve the research performance of } \\
\text { faculty members }\end{array}$ & 3.86 & 4.11 & 4.56 & 4.08 & 4.25 & 0.78 \\
\hline $\begin{array}{l}\text { 5. To improve the learning achievement of } \\
\text { students }\end{array}$ & 3.75 & 3.89 & 4.51 & 4.26 & 4.26 & 0.74 \\
\hline $\begin{array}{l}\text { 6. To improve the overall performance of the } \\
\text { institution }\end{array}$ & 4.00 & 4.23 & 4.34 & 4.05 & 4.18 & 0.73 \\
\hline
\end{tabular}

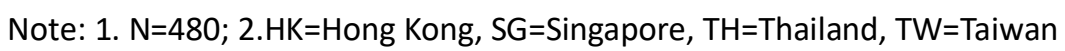

In addition, the respondents who are in Thailand show the highest level of agreement on the five reasons of numbers 2, 3, 4, 5, and 6. In contrast, the respondents who are in Hong Kong demonstrate relatively low level of agreement on the five reasons of numbers $1,3,4,5$, and 
6. In general, it may be inferred that the responding faculty members and librarians in Thailand probably exhibit a higher level of motivation to develop faculty-librarian collaboration for promoting information literacy education and the use of library resources, as well as improving teaching, research, and learning performance in the universities. The responding faculty members and librarians in Hong Kong, in contrast, seem to demonstrate a relatively lower level of motivation to develop faculty-librarian collaboration than those who are in other regions.

\section{(b) Methods for Building Faculty-Librarian Collaborative Relationships}

Table 6 shows that "Librarians have regular, active contact with faculty members to understand their opinions and needs" (average=4.13), "The library establishes a liaison librarian program" (average $=4.10$ ) and "The library establishes a subject-specialist librarian program" (average=4.06) are the most prevalent three methods adopted by responding faculty members and librarians to build their collaborative relationship. This finding suggests that librarians play a key role in building the collaborative relationship between faculty members and librarians. In other words, liaison librarians and subject specialist librarians can take a more active role in building a productive collaborative relationship with faculty members of different academic departments.

Table 6: Comparison of the Differences in the Methods for Building Faculty-Librarian Collaborative Relationships in Hong Kong, Singapore, Taiwan, and Thailand

\begin{tabular}{|c|c|c|c|c|c|c|}
\hline \multirow[b]{2}{*}{ Method } & \multicolumn{4}{|c|}{ Location of university } & \multirow[b]{2}{*}{ Average } & \multirow[b]{2}{*}{ SD } \\
\hline & $\begin{array}{c}\mathrm{HK} \\
\text { (mean) }\end{array}$ & $\begin{array}{c}\text { SG } \\
\text { (mean) }\end{array}$ & $\begin{array}{c}\text { TH } \\
\text { (mean) }\end{array}$ & $\begin{array}{c}\text { TW } \\
\text { (mean) }\end{array}$ & & \\
\hline $\begin{array}{l}\text { 1. The library establishes a liaison librarian } \\
\text { program }\end{array}$ & 4.13 & 4.11 & 4.04 & 4.15 & 4.10 & 0.69 \\
\hline $\begin{array}{l}\text { 2. The library establishes a subject-specialist } \\
\text { librarian program }\end{array}$ & 3.91 & 4.17 & 4.05 & 4.09 & 4.06 & 0.75 \\
\hline $\begin{array}{l}\text { 3. Librarians have regular, active contact with } \\
\text { faculty members to understand their } \\
\text { opinions and needs }\end{array}$ & 4.14 & 4.21 & 4.11 & 4.12 & 4.13 & 0.67 \\
\hline $\begin{array}{l}\text { 4. Librarians frequently actively take part in } \\
\text { departmental faculty meetings or activities }\end{array}$ & 3.80 & 3.83 & 3.95 & 3.90 & 3.90 & 0.86 \\
\hline $\begin{array}{l}\text { 5. Faculty members frequently take part in the } \\
\text { library's seminars or promotion activities }\end{array}$ & 3.70 & 3.40 & 3.88 & 4.14 & 3.91 & 0.77 \\
\hline
\end{tabular}

Note: $1 . \mathrm{N}=480 ; 2$.HK=Hong Kong, SG=Singapore, $\mathrm{TH}=$ Thailand, TW=Taiwan 
Looking at the mean scores for each location of university, the responding faculty members and librarians in Singapore obviously exhibit a relatively lower level of agreement than those who are in Hong Kong, Taiwan, and Thailand regarding the method of "Faculty members frequently take part in the library's seminars or promotion activities." If we refer back to the data in Table 4, we'll find that the respondents in Singapore also show the lowest level value of collaborative culture in the dimension of "Mutual understanding and communication." These findings may indicate that the value level of collaborative culture can influence the behavior of building collaborative relationship among faculty members and librarians.

\section{(c) Models for Developing Faculty-Librarian Collaboration}

The mean score of the models "Promoting library use and/or information literacy" is relatively higher than other collaborative models as shown in Table 7. Its average scores reached 4.42. This result is consistent with the finding in the survey studies of Gallegos and Wright (2000) and Library Journal and Gale (2015). They concur that information literacy education is the most essential service for academic librarians and faculty members to collaborate with each other. It is confirmed that library instruction or information literacy education is the most widely used model adopted by librarians and faculty members to collaborate with each other., By contrast, the mean scores of "Designing an assignment or homework for a class/course" (average=3.38), "Preparing teaching materials for a class/course" (average=3.57), and "Conducting a research project" (average=3.64) were relatively lower than other models.

In general, it is evident that the responding faculty members and librarians in Thailand and Taiwan exhibit a higher level of preference to adopt the collaborative models of "Co-teaching in a class", "Preparing teaching materials for a class/course", "Designing an assignment for a class/course", "Conducting a research project", Organizing a book club", and "Establishing a teaching website" than those who are in Hong Kong and Singapore.

Furthermore, 27 respondents provided other types of collaborative models with which they have had experience in the past years. Twenty types of faculty-librarian collaborative models in Hong Kong, Singapore, Taiwan, and Thailand are summarized by the researchers as shown in Table 8. According to the functions of collaboration, the 20 different types of facultylibrarian collaborative models are divided into three categories, including library serviceoriented, faculty teaching-oriented, and faculty research-oriented. 
Table 7: Comparison of the Differences in the Models for Developing Faculty-Librarian Collaboration in Hong Kong, Singapore, Taiwan, and Thailand

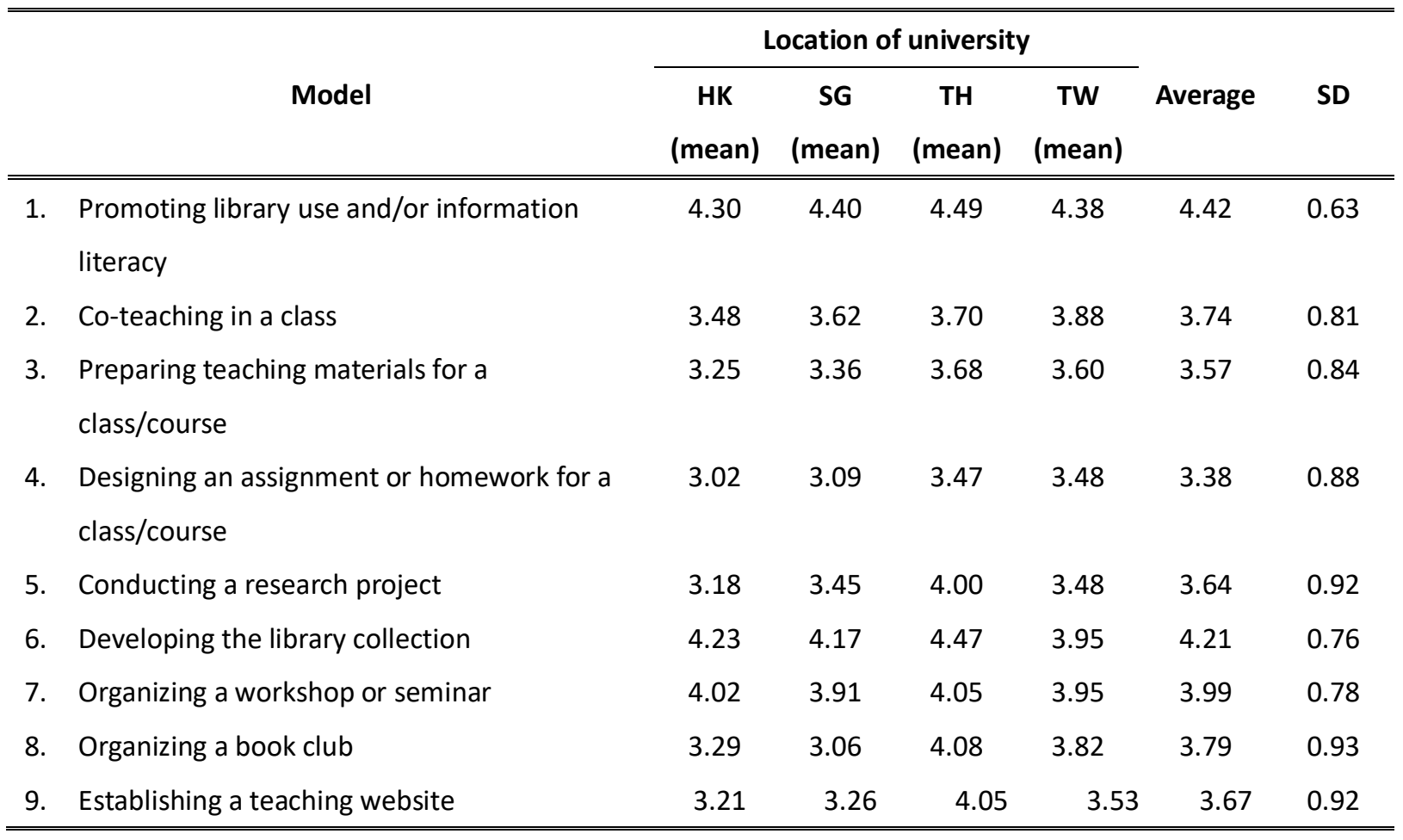

Note: $1 . \mathrm{N}=480 ;$ 2.HK=Hong Kong, SG=Singapore, $\mathrm{TH}=$ Thailand, TW=Taiwan

Table 8: Types of Faculty-Librarian Collaborative Model

\begin{tabular}{ll}
\hline \multicolumn{1}{c}{ Category } & \multicolumn{1}{c}{ Type of Model } \\
\hline \hline Library service- & 1. Promoting library use; 2. Promoting information literacy; 3. Developing a \\
oriented & library collection; 4. Organizing a workshop or seminar; 5. Organizing a book \\
& club; 6. Organizing an exhibition (e.g. book fairs, student works); 7. Collaborating \\
& in data curation initiative; 8. Creating a digital project (e.g. institutional \\
& repository); 9. Co-building a library automation system \\
\hline Faculty teaching- & 1.Co-teaching in a class; 2. Preparing teaching materials for a class/course (e.g. \\
oriented & Moocs); 3. Establishing a teaching website/course blog; 4. Designing an \\
& assignment or homework for a class/course; 5. Organizing an academic event \\
& (e.g. guest talk, book launch); 6. Building e-portfolio of faculty/student works \\
\hline Faculty research- & 1.Conducting a research proposal/project/paper; 2. Jointly publishing (e.g. \\
oriented & journal articles, book chapters, student research projects); 3. Hosting an open \\
& $\begin{array}{l}\text { access e-journal; 4. Collaborating in faculty's research data management; and 5. } \\
\text { Preparing a research evaluation (e.g. research assessment exercise in Hong Kong) }\end{array}$ \\
\hline \hline
\end{tabular}

\section{(d) Success Factors for Conducting Faculty-Librarian Collaborative Projects}

The mean scores of all of the success factors are higher than 4.0, as shown in Table 9. This shows that all of the identified factors are essential for faculty members and librarians to 
successfully implement collaborative projects. However, both success factors "Effective communication and interaction" (average $=4.41$ ) and "Mutual respect and trust" (average $=4.37$ ) are slightly higher than the others. This finding suggests that a successful faculty-librarian collaborative project must rely on effective communication and a climate of mutual respect and trust between them.

Table 9: Comparison of the Differences in Success Factors for Developing Faculty-Librarian Collaborative Projects in Hong Kong, Singapore, Taiwan, and Thailand

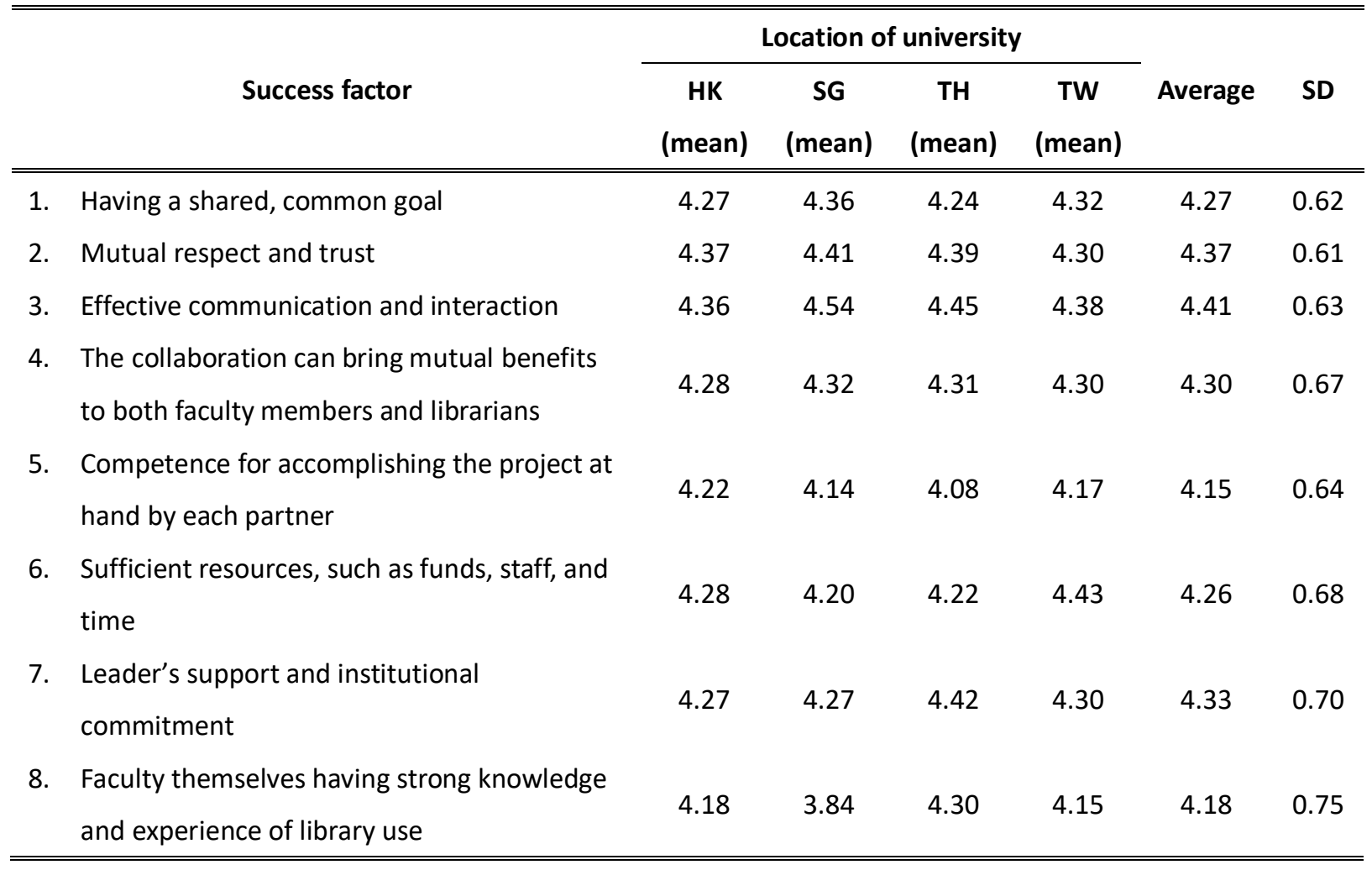

Note: 1 . $\mathrm{N}=480 ; 2$.HK=Hong Kong, $\mathrm{SG}=$ Singapore, $\mathrm{TH}=$ Thailand, TW=Taiwan

\section{(e) Difficulties Faced by Faculty Members and Librarians to Conduct a Faculty- Librarian Collaborative Project}

The highest level of difficulty for the responding faculty members and librarians to work together in collaborative projects are "Not having enough time to work together" (average=3.99) and "Unfamiliarity with each other" (average=3.95), as shown in Table 10. Based on this result, time constraint seems to constitute the most serious obstacle for both faculty members and librarians initiating collaborative projects. In addition, if both faculty members and librarians were less aware of each other, and had less interest in working with each other, it could be much more difficult for them to conduct collaborative projects. 
Table 10: Comparison of the Differences in Difficulties for Developing Faculty-Librarian Collaborative Projects in Hong Kong, Singapore, Taiwan, and Thailand

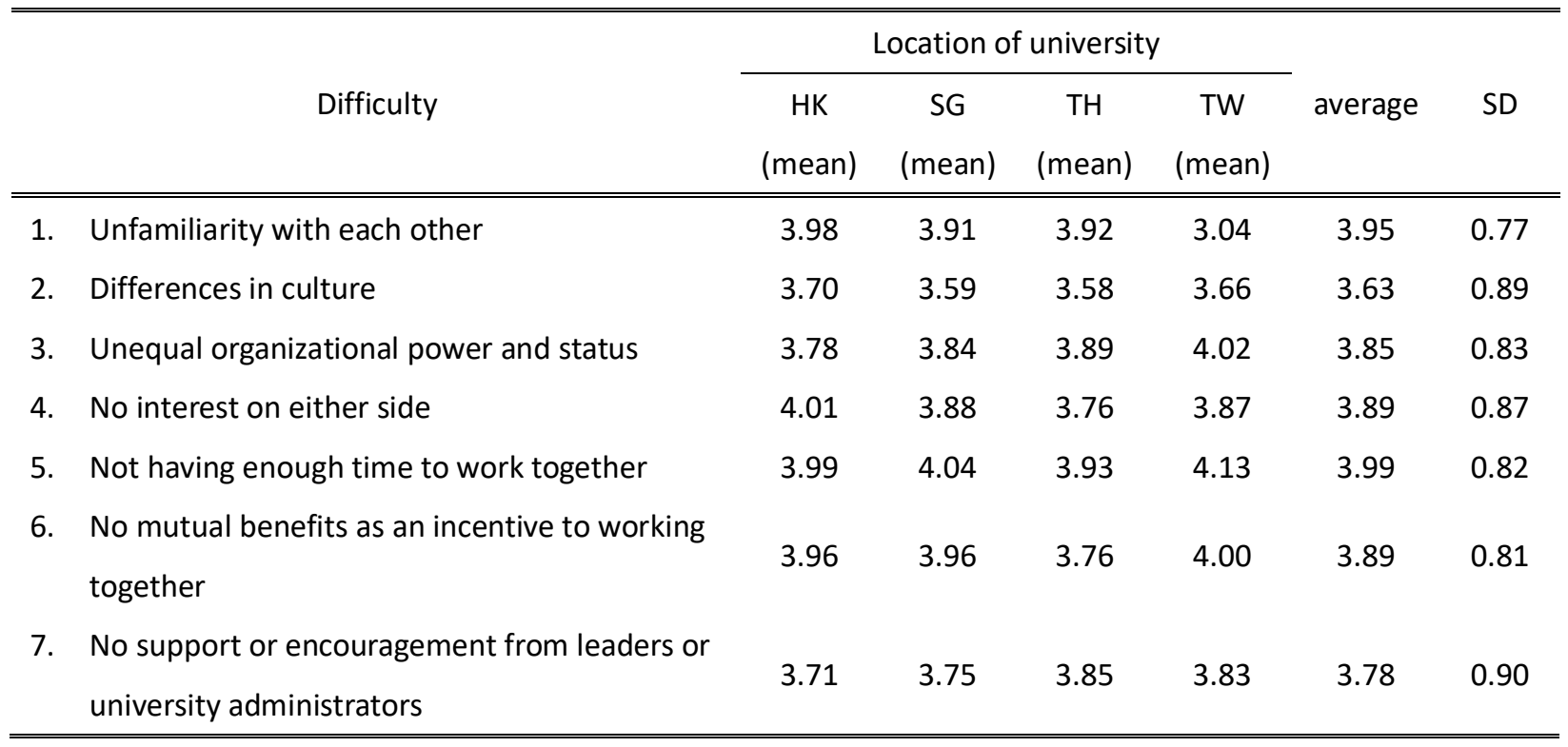

Note: $1 . \mathrm{N}=480 ; 2$.HK=Hong Kong, $\mathrm{SG}=$ Singapore, $\mathrm{TH}=$ Thailand, $\mathrm{TW}=$ Taiwan

\section{Comments and Suggestions of the Responding Faculty Members and Librarians}

There is an open question at the end of the questionnaire for collecting some qualitative data. The question is "If you have had experience in collaborating with faculty members/librarians, please feel free to describe your experience and provide your comments or suggestions." Based on the comments and suggestions of the respondents, several important findings are summarized as follows:

(a) Most of the responding faculty members and librarians have had pleasant experiences working with each other, especially in Thailand.

(b) A librarian from Hong Kong asserted that faculty members have too many priorities at hand, and therefore, it is important to address the question "What is in it for me?" for faculty members. This means that it must be made clear to faculty members what kinds of benefits and/or incentives that they could obtain from the collaboration. Otherwise, it is not easy for faculty members to work with librarians spontaneously.

(c) A number of negative feelings regarding faculty-librarian collaboration are described by some respondents. For example, one of the responding faculty members from Hong Kong reported that the library is often ignored in her university. Librarians usually play a passive role in faculty-librarian collaborative projects. This means that it is difficult for librarians to work with faculty members unless they receive a request for collaborative projects from faculty members. In addition, a Taiwan faculty member complained that his or her institutional administrators and leaders did not understand or care about the functions of the library. It was consequently difficult for librarians to implement any collaborative project with faculty members due to 
limited resources, such as budget reductions and manpower constraints. A faculty member of Thailand commented that academic faculty culture sometimes prevents collaborative work. Accordingly, faculty members, executive administrators, and library leaders in universities indeed play an important role in the success of the implementation of faculty-librarian collaborative projects.

(d) Librarians need to develop different types of faculty-librarian collaborative models for different academic departments. A faculty member from Hong Kong asserted that academic departments have very different organizational and work cultures, (e.g., some like to work with the library, but others may not like librarians to bother them). There is thus no single model or practice that can fit the needs of library collaboration with each department.

(e) Many responding librarians from Singapore presented many comments. It is obvious that most Singaporean librarians are strongly motivated to collaborate with faculty members and strive to promote their value-added roles for faculty-librarian collaborations. On the other hand, it seems difficult to conduct a faculty-librarian collaborative project in Singapore due to a weak desire of faculty members, little support from faculty members, and a lower status of librarians in the universities. In addition, one of the Singaporean librarians reported that collaborations with faculty are often cultivated at a person-to-person level and not with the school. This means that if a faculty member leaves, the collaborative projects usually stop. Therefore, another librarian suggested that a strong top-down approach would work better for faculty-librarian collaboration.

\section{CONCLUSIONS AND SUGGESTIONS}

Seven elements that can construct the concept of faculty-librarian culture are explored in this study. They are: (1) Organizational collaborative environment; (2) Mutual benefit and responsibility in collaboration; (3) Collaborative commitment; (4) Collaborative leadership; (5) Mutual understanding and communication; (6) Mutual respect and trust; and (7) Collaborative relationship and interaction.

This study concluded that the responding faculty members and librarians in different regions of Southeast Asia, including Hong Kong, Singapore, Taiwan, and Thailand indeed exhibited distinctions in the levels of values toward faculty-librarian collaborative culture. They also differed in the perceptions/experiences regarding the current development of facultylibrarian collaboration. In addition, based on the results and findings of this study, the researchers assumed that the concept of faculty-librarian collaboration has probably 
developed and been accepted by faculty members and librarians in the universities of Thailand and Taiwan slightly more than in the universities of Hong Kong and Singapore.

The researchers proposed a number of implications and suggestions for librarians and faculty members to develop faculty-librarian collaborations in Hong Kong, Singapore, Taiwan, and Thailand respectively, as follows:

(a) This study found that it is relatively difficult for librarians to initiate collaborative projects with faculty members in Singapore due to a weak desire of faculty members, little support from faculty members, and a lower status of librarians in the universities. It is therefore important to address the issue of why faculty members often exhibit a weak desire to initiate change and offer little support. We consider that this may be the result of a lack of communication and mutual understanding between faculty members and librarians in Singapore. Therefore, we suggest that faculty members in Singapore may try to contact with librarians when they need assistance for teaching or research. They will probably find many intelligent and responsive librarians who are available and capable to help them. Oppositely, librarians also need to conceptualize some attractive projects or activities in which to persuade faculty members to participate.

(b) Faculty members and librarians in Hong Kong seem to spend less time and effort to work together for faculty-librarian collaborative projects. In addition, librarians usually play a passive role and do not find it easy to work with faculty members unless they receive a request from faculty members to conduct collaborative projects together. Therefore, librarians in the universities of Hong Kong may initially consider becoming more acquainted with faculty members. They then probably need to proactively spend time and effort to talk with faculty members and identify what faculty members actually need and want from the collaborations. Finally, they can find optimal opportunities to collaborate with faculty members.

(c) It is evident that faculty-librarian collaborations in Thailand have developed to a relatively high level, especially in promoting information literacy education. Librarians in the universities of Thailand have established a form of liaison librarian program. The main aim here is to strengthen the interactive relationships with different academic departments. It thus involves proactively meeting faculty members' specific needs for collaborative services instead of serving as a contact person. This could probably create better opportunities for librarians to develop different types of advanced faculty-librarian collaborative projects.

(d) Determining how to establish a collaborative environment in institutions seems to be the biggest challenge for faculty members and librarians in Taiwan. Both faculty members and librarians in the universities of Taiwan need to change the ways in 
which they teach and work. They may try to convince institutional administrators and library directors to establish formal incentive policies. These incentives could include granting performance credits and encouraging faculty members and librarians to implement any kind of faculty-librarian collaborative project.

(e) Finally, the researchers consider that the distinctions in these countries and regions are largely influenced by, and are associated with, their respective national cultures. Therefore, future studies could be conducted to analyze and compare the differences of faculty-librarian collaborative culture and collaborative development in Hong Kong, Singapore, Taiwan, and Thailand from the perspective of national culture. In addition, the researchers may expand the investigation into other countries and regions of Asia in the future.

\section{ACKNOWLEDGEMENT}

This research received no specific grant from any funding agency in the public, commercial, or not-for profit sectors.

\section{REFERENCES}

Andayani, U. 2017. The collaboration between librarians and faculties in preserving and publishing the intellectual heritages through the institutional repositories: a case at Syarif Hidayatullah State Islamic University, Jakarta. Library Philosophy \& Practice (ejournal). 1517. Available at: https://digitalcommons.unl.edu/libphilprac/1517/.

Caspers, J. and Lenn, K. 2000. The future of collaboration between librarians and teaching faculty. In Raspa, D. \& Ward, D. (Eds.), The collaboration imperative: Librarians and faculty working together in the information universe (pp.148-158). Chicago, IL: ACRL.

Cha, T. Y. and Hsieh, P. N. 2009. A case study of faculty attitudes towards collaboration with librarians to integrate information literacy into the curriculum. Journal of Educational Media and Library Sciences, Vol.46, no.4: 440-467.

Chu, S. K. W., Chow, K. and Tse, S. K. 2011. Using collaborative teaching and inquiry projectbased learning to help primary school student develop information literacy and information skills. Library \& Information Science Research, no.33: 132-143.

Cook, D. 2000. Creating connections: a review of the literature. In Raspa, D. and Ward, D. (Eds.), The collaboration imperative: Librarians and faculty working together in the information universe (pp.19-38). Chicago, IL: ACRL.

Cox, T. H., Lobel, S. A. and McLeod, P. L. 1991. Effects of ethnic group cultural differences on 
cooperative and competitive behavior on a group task. Academy of Management Journal, Vol.34, no.4: 827-847.

Doskatsch, I. 2003. Perceptions and perplexities of the faculty-librarian partnership: an Australian perspective. Reference Services Review, Vol. 31, no.2: 111-121.

Farber, E. 1999. Faculty-librarian cooperation: A personal retrospective. Reference Services Review, Vol.27, no.3: 229-234.

Gallegos, B. and Wright, T. 2000. Collaborations in the field: Examples from a survey. The Collaborative imperative: Librarians and faculty working together in the information universe. Chicago: ACRL.

Hardesty, L. 1991. Faculty and the library: The undergraduate experience. Norwood, NJ: Ablex Publishing.

Hardesty, L. 1995. Faculty culture and bibliographic instruction: an exploratory analysis. Library Trends, Vol.44, no.2: 339-367.

Huxham, C. 1996. Collaboration and collaborative advantage. In Huxham, C. (Ed.), Creating collaborative advantage (pp.1-18). London: SAGE Publishing.

Jenkins, P. O. 2005. Faculty-librarian relationships. Oxford: Chandos Publishing.

Kraat, S. B. (Ed.) 2005. Relationships between teaching faculty and teaching librarians. Binghamton, NY: Haworth Information Press.

Library Journal and Gale. 2015. Bridging the librarian-faculty gap in the academic library 2015. Available at: http://lj.libraryjournal.com/downloads/2015-bridging-the-librarianfaculty-gap-in-the-academic-library/.

Lo, P. et al. 2014. The role of the school libraries as information literacy specialists. New Library World, Vol.115, no.7/8: 314-339.

Magnusson, P., Peterson, R. and Westjohn, S. A. 2014. The influence of national cultural values on the use of rewards alignment to improve sales collaboration. International Marketing Review, Vol.31, no.1: 30-50.

Maitaouthong, T., Tuamsuk, K., and Tachamanee, Y. 2011. Factors affecting the integration of information literacy in the teaching and learning of general education course. Journal of Educational Media and Library Sciences, Vol.49, no.2: 265-291.

Maitaouthong, T., Tuamsuk, K., and Tachamanee, Y. 2012. The roles of university libraries in supporting the integration of information literacy in the course instruction. Malaysia Journal of Library and Information Science, Vol.17, no.1: 51-64.

Matessich, P. W. and Money, B. R. 1992. Collaboration: What makes it work. St. Paul, MI: Amherst H. Wilder Foundation.

Mees, G. W. 2008. The relationships among principal leadership, school culture, and student achievement in Missouri Middle Schools. (Unpublished doctoral dissertation). Columbia, Missouri: University of Missouri.

Mokhtar, I. A. and Majid, S. 2005. Use of school libraries by teachers in Singapore schools. 
Library Review, Vol.54, no.2: 108-118.

Mokhtar, I. A. and Majid, S. 2006. An exploratory study of the collaborative relationship between teachers and librarians in Singapore primary and secondary schools. Library \& Information Science Research, no.28: 265-280.

Raspa, D. and Ward, D. 2000. Listening for collaboration: Faculty and librarians working together. In Raspa, D. and Ward, D. (Eds.), The collaboration imperative: Librarians and faculty working together in the information universe (pp.1-18). Chicago, IL: ACRL.

Rockman, I. F. 2001. Partnership: yesterday, today, and tomorrow. Reference Services Review, Vol.29, no.3: 93-94.

Schein, E. H. 1992. Organizational culture and leadership (2nd ed.). San Francisco, CA: JosseyBass.

Segal, J. A. 2001. Collaboration between theory and evidence-based practice-two cultures: Librarians and professors. Paper presented at the 66th IFLA Council and General Conference Jerusalem, Israel. Available at: http://archive.ifla.org/IV/ifla66/ papers/053-99e.htm

Srivastava S. B. and Banaji, M. R. 2011. Culture, cognition, and collaborative networks in organizations. American Sociological Review, Vol.76, no.2: 207-233.

Southern, N. L. 2005. Creating cultures of collaboration that thrive on diversity: A transformational prospective on building collaborative capital. In Beyerlein, M. M., Beyerlein, S.T. and Kennedy, F. A. (Eds.), Collaborative capital: Creating intangible value (pp. 33-72). London: Elsevier, Ltd.

Wagner, T. 1998. Changes as collaborative inquiry: A 'constructivist' methodology for reinventing schools. Phi Delta Kappan, Vol.79, no.7, 512-517.

Wei, K. 2009. National culture in practice: its impact on knowledge sharing in global virtual collaboration. (Unpublished doctoral dissertation). Syracuse University, Syracuse, NY.

Wijayasundara, N. D. 2008. Faculty-library collaboration: a model for University of Colombo. The International Information and Library Review, no.40: 180-198.

Yu T. and Chen, C. C. 2018. Faculty-librarian collaborative culture and current development in the colleges and universities in Taiwan. Journal of Educational Media and Library Sciences, Vol.55, no.1:5-37.

Yu. T. and Huang, J. H. 2009. A case study of faculty-librarian collaboration on promoting the use of library resources and services in the Jinwen University of Science and Technology. Journal of Educational Media and Library Sciences, Vol.46, no.3: 297-321. 